\title{
WOODSMOKE MARKER LEVOGLUCOSAN: KINETICS IN A SELF-EXPERIMENT
}

\section{HANNS MOSHAMMER ${ }^{1}$, STEFAN WEISS ${ }^{2}$, and MANFRED NEUBERGER ${ }^{1}$}

\author{
${ }^{1}$ Medical University of Vienna, Austria \\ Institute of Environmental Health, ZPH \\ ${ }^{2}$ Umweltbundesamt GmbH, Vienna, Austria
}

\begin{abstract}
Objectives: Concerns on climate change are leading to the renaissance of wood burning and particulate exposures. Levoglucosan is used as a marker of woodsmoke in air and urine. Objectives: Contribution of data on urinary excretion of levoglucosan, to improve biomonitoring and source apportionment of woodsmoke. Materials and Methods: 1, 3, 5, and 7 hours after $5 \mathrm{mg}$ of levoglucosan had been administered orally, urinary excretion was measured by HPLC and mass spectrometry. Results: After oral intake, urine concentrations increased rapidly, reached highest values after 3 hours, and after 7 hours approximately $70 \%$ of the administered dose was excreted. Conclusions: Urinary levoglucosan may be used for biomonitoring of woodsmoke exposure on the same day.
\end{abstract}

Key words:

Woodsmoke Biomonitoring, Levoglucosan, Human urine, Excretion

\section{INTRODUCTION}

Levoglucosan is considered to be a specific marker of woodsmoke used in environmental monitoring of source-specific air pollutants [1,2]. Nowadays, rising oil prices and threats of climate change have brought about a revival of "good old" wood stoves which often are rather old than good [3]. This has also brought renewed interest into markers of woodsmoke exposure. It is well established that aerosol from incineration sources is of special health relevance as an air pollutant. Only few studies have attempted to estimate the relative impact of aerosols from wood burning, mostly due to the lack of available data [4,5]. This situation could be improved by either intensifying ambient monitoring of markers or by applying specific markers of exposure in biomonitoring. Levoglucosan has also been proposed as a biomonitoring marker [6-8], but little has been known until now about its kinetics in humans. Animal studies indicate that most of the substance is excreted fast and unchanged [7], which would indicate low toxicity. Nevertheless, Miyakawa et al. [9] report some evidence of a carcinogenic effect in mice. In spite of this information, we decided to study the kinetics of orally administered levoglucosan in two of the authors (Hanns Moshammer $-\mathrm{HM}=49$, and Manfred Neuberger $\mathrm{MN}=63$, both male) serving as volunteers.

\footnotetext{
The authors declare that the procedures followed were in accordance with the ethical standards of the responsible committee on human experimentation (Ethics Committee, Medical University of Vienna) and with the Helsinki Declaration of 1975, as revised in 1983. The authors Hanns Moshammer (HM) and Manfred Neuberger (MN) experimented on themselves with a low dose, comparable to involuntary environmental exposure, and asked Stefan Weiss to analyze the excretion in their urine. HM and MN are independent and fully informed researchers.

Received: August 23, 2011. Accepted: January 3, 2012.

Address reprint request to M. Neuberger, Institute of Environmental Health, Kinderspitalgasse 15, A-1090 Wien, Austria, (e-mail: manfred.neuberger@meduniwien.ac.at).
} 


\section{MATERIALS AND METHODS}

We hypothesized that orally administered levoglucosan is excreted unchanged, in a short time, via urine. To test this hypothesis, the two volunteers provided early morning urine on July 20th, a fine day in summer with no apparent woodsmoke present during the previous days. Crystalline levoglucosan weighing $20.62 \mathrm{mg}$ was dissolved in $4 \mathrm{ml}$ of water. At 8:45 a.m. both volunteers drank $1 \mathrm{ml}$ of this solution each, containing $5.155 \mathrm{mg}$ of levoglucosan $(60,65 \mu \mathrm{g} / \mathrm{kg}$ in $\mathrm{HM}$ and $68,73 \mu \mathrm{g} / \mathrm{kg}$ in $\mathrm{MN})$. Urine samples were provided $1,3,5$, and 7 hours afterwards. Urine volume was measured and the samples were delivered to the laboratory at the Umweltbundesamt $\mathrm{GmbH}$ on the same day.

Levoglucosan (99\%) was purchased from Aldrich (Vienna, Austria), acetonitrile, water (HPLC grade) and carbon labeled levoglucosan from LGC Promochem (Wesel, Germany).

The samples were spiked with the isotopically labeled surrogate standard and diluted 1:10 in HPLC water.

The analysis of levoglucosan was performed on a HP1200 HPLC (Agilent Technologies, Vienna, Austria) consisting of a membrane degasser, a binary high-pressure pump, an automatic sampler and a column heater, connected to a 4000 QTrap mass spectrometer (Applied Biosytems, Darmstadt, Germany). Chromatographic separation was achieved by coupling two $150 \times 2.0 \mathrm{~mm}$ Shodex ODP2HP2D columns (Phenomenex, Aschaffenburg, Germany) with $5 \mu \mathrm{m}$ particle size at the temperature of $25^{\circ} \mathrm{C}$. The eluents were acetonitrile (A) and HPLC water (B). Gradient elution was used starting with $1 \% \mathrm{~A}$ at $0 \mathrm{~min}$, held for $1 \mathrm{~min}$, increased to $20 \% \mathrm{~A}$ at $7 \mathrm{~min}$, held for $2 \mathrm{~min}$, increased to $70 \% \mathrm{~A}$ at $10 \mathrm{~min}$, held for $2 \mathrm{~min}$, reduced to $1 \% \mathrm{~A}$ at $13 \mathrm{~min}$. The Total Run Time was $45 \mathrm{~min}$. The injection volume was $10 \mu \mathrm{l}$.

Ionization was performed in the negative electrospray mode. The source was operated at the temperature of $400^{\circ} \mathrm{C}$ and the voltage of $4500 \mathrm{~V}$. Nitrogen was provided by a nitrogen generator (CMC instruments, Eschborn, Germany) and used as nebulizer, curtain and collision cell gas. Multiple reaction monitoring (MRM) mode was used for quantitative determination with the following MS/MS transitions: Levoglucosan (160.9 to 112.9 and 160.9 to 70.8 for qualitative confirmation), Levoglucosan-13C6 (166.9 to 104.8).

\section{RESULTS}

Table 1 shows the findings of the urine analyses. Even in the morning samples that had been collected before the administration of levoglucosan the substance was detected at $5-6 \mu \mathrm{g} / \mathrm{ml}(\mathrm{HM}=5.8 ; \mathrm{MN}=5.2)$. This is in accordance with the findings in pooled samples of morning urine collected from 10 randomly selected Viennese female participants of a biomonitoring study (unpublished data). Furthermore, this is confirmed by a recent study which stated that the levoglucosan background level is present due to dietary influences [10]. After the oral intake, urine concentrations increased rapidly and reached the highest values after 3 hours (Figure 1). After 7 hours, approximately $70 \%$ of the administered dose was excreted in urine (Figure 2). The logarithm of masses excreted after 3, 5 and 7 hours showed a nearly linear decrease with an estimated half-life of levoglucosan in urine between 4 and 5 hours.

Table 1. Urine concentrations and masses of levoglucosan after oral intake of $5.155 \mathrm{mg}(60,65 \mu \mathrm{g} / \mathrm{kg}$ in HM and $68,73 \mu \mathrm{g} / \mathrm{kg}$ in MN)

\begin{tabular}{lrrrrrr}
\hline Hour & \multicolumn{2}{c}{$\begin{array}{c}\text { Levoglucosan } \\
\text { conc. } \\
(\mu \mathrm{g} / \mathrm{ml})\end{array}$} & \multicolumn{2}{c}{$\begin{array}{c}\text { Urine } \\
\text { volume } \\
(\mathrm{ml})\end{array}$} & \multicolumn{2}{c}{$\begin{array}{c}\text { Levoglucosan } \\
\text { mass } \\
(\mu \mathrm{g})\end{array}$} \\
\cline { 2 - 7 } & \multicolumn{1}{c}{ HM } & MN & HM & \multicolumn{1}{c}{ MN } & \multicolumn{1}{c}{ HM } & \multicolumn{1}{c}{ MN } \\
\hline 0 & 5.8 & 5.2 & & & & \\
1 & 13.0 & 8.5 & 70.0 & 42.0 & 910.0 & 357.0 \\
3 & 14.0 & 14.0 & 84.0 & 84.0 & 1176.0 & 1176.0 \\
5 & 16.0 & 4.3 & 58.0 & 212.0 & 928.0 & 911.6 \\
7 & 13.0 & 8.3 & 68.0 & 92.0 & 884.0 & 763.6 \\
\hline
\end{tabular}

HM - Hanns Moshammer, MN - Manfred Neuberger. 


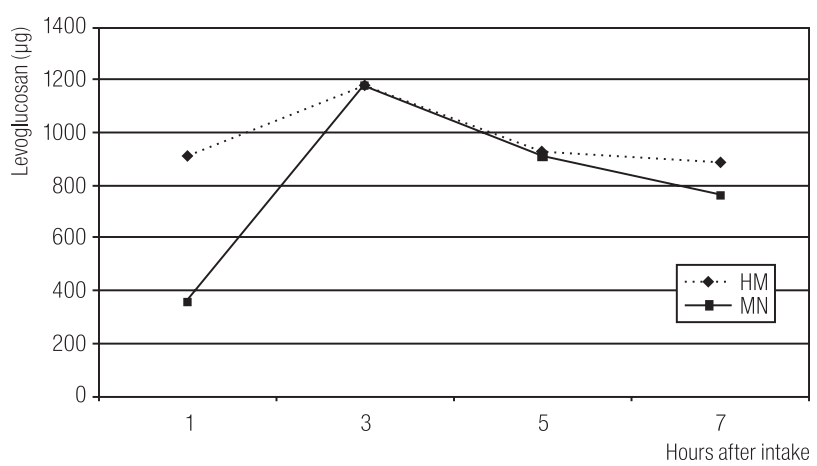

Abbreviations as in Table 1.

Fig. 1. Excretion of levoglucosan in urine after the intake of $5155 \mu \mathrm{g}$

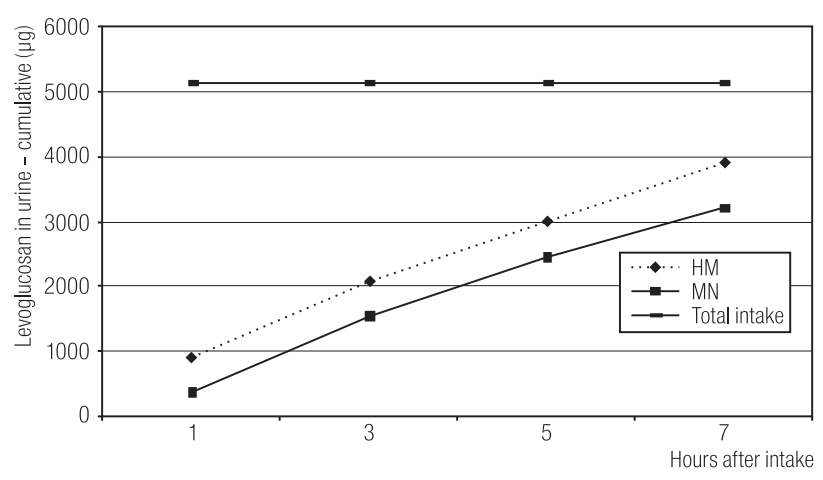

Abbreviations as in Table 1.

Fig. 2. Levoglucosan in urine - cumulative excretion

\section{DISCUSSION}

Recently, the analysis of levoglucosan in air and urine has been used more frequently as a marker of exposure to woodsmoke [6,8]. To our knowledge, this is the first study following oral administration in humans. Animal studies [7] indicate a short half-life with fast excretion of the unchanged substance. We were able to show that the same is true for human metabolism.

While Neitzel et al. [8] reported an association between levoglucosan and $\mathrm{CO}$ exposure of firemen fighting wood fires, Hinwood et al. [6] found no increase in levoglucosan concentration in firemen after a training fire. Both studies did not control for ambient exposure. Bergauff et al. [10] found an increase of the urinary levoglucosan level within 2 hours of caramel consumption and no consistent increase after exposure to woodsmoke, suspecting a stronger influence of dietary levoglucosan. In our experiment, all sweets (in particular caramelized ones) and inhalation of woodsmoke (except that from low urban background in summer) had been avoided. Our findings show that levoglucosan concentrations not only depend on the intake, but also depend strongly on the timing of the samples due to a short halftime of the substance. To establish levoglucosan as a valuable biomarker of individual exposure more research on temporal and individual variability is needed. On the other hand, on a population level we have recently found (unpublished data) that levoglucosan in urine can reliably predict exposure to polycyclic aromatic hydrocarbons.

\section{ACKNOWLEDGEMENTS}

Material and analytical apparatus for this experiment was provided by the Federal Environmental Protection Agency. All authors declare to have no conflicts of interests.

\section{REFERENCES}

1. Puxbaum H, Caseiro A, Sánchez-Ochoa A, Kasper-Giebl A, Claeys M, Gelencsér A, et al. Levoglucosan Levels at Background Sites in Europe for Assessing the Impact of Biomass Combustion on the European Aerosol Background. Geophys Res 2007;112:D23S05. DOI: 10.1029/2006JD008114.

2. Iinuma Y, Böge O, Gräfe R, Hermann H. Methyl-Nitrocatechols: Atmospheric Tracer Compounds for Biomass Burning Secondary Organic Aerosols. Environ Sci Technol 2010;44:8453-9.

3. Bélanger D, Gosselin P, Valois P, Abdous B. Use of residential wood heating in a context of climate change: a population survey in Québec (Canada). BMC Public Health 2008;8:184.

4. Naeher LP, Brauer M, Lipsett M, Zelikoff JT, Simpson CD, Koenig JQ, et al. Woodsmoke Health Effects: A Review. Inhalation Toxicology 2007;19:67-106. 
5. Morgan G, Sheppeard V, Khalaj B, Ayyar A, Lincoln D, Jalaludin B, et al. 2010. Effects of Bushfire Smoke on Daily Mortality and Hospital Admissions in Sydney, Australia. Epidemiology 2010;21:47-55.

6. Hinwood AL, Trout M, Murby J, Barton C, Symons B. Assessing urinary levoglucosan and methoxyphenols as biomarkers for use in woodsmoke exposure studies. Sci Total Environ 2008;402:139-46.

7. Migliaccio CT, Bergauff MA, Palmer CP, Jessop F, Noonan CW, Ward TJ. Urinary Levoglucosan as a Biomarker of Wood Smoke Exposure: Observations in a Mouse Model and in Children. Environ Health Perspect 2009;117:74-9.
8. Neitzel R, Naeher LP, Paulsen M, Dunn K, Stock A, Simpson CD. Biological monitoring of smoke exposure among wildland firefighters: a pilot study comparing urinary methoxyphenols with personal exposures to carbon monoxide, particular matter, and levoglucosan. J Expo Sci Environ Epidemiol 2009;19:349-58.

9. Miyakawa Y, Nishi Y, Kato K, Sato H, Takahashi M, Hayashi Y. Initiating activity of eight pyrolysates of carbohydrates in a two-stage mouse skin tumorigenesis model. Carcinogenesis 1991;12:1169-73.

10. Bergauff MA, Ward TJ, Noonan CW, Migliaccio CT, Simpson $\mathrm{CD}$, Evanoski AR, et al. Urinary levoglucosan as a biomarker of wood smoke: Results of human exposure study. J Expo Sci Environ Epidemiol 2010;20:385-92.

This work is available in Open Access model and licensed under a Creative Commons Attribution-NonCommercial 3.0 Poland License - http://creativecommons.org/ licenses/by-nc/3.0/pl/deed.en. 